\title{
High susceptibility of activated lymphocytes to oxidative stress-induced cell death
}

\author{
GIOVANNA R. DEGASPERI, ROGER F. CASTILHO and ANIBAL E. VERCESI
}

Departamento de Patologia Clínica, Faculdade de Ciências Médicas, Universidade Estadual de Campinas (UNICAMP) 13083-887 Campinas, SP, Brasil

Manuscript received on August 31, 2007; accepted for publication on January 21, 2008; contributed by ANIBAL E. VERCESI*

\begin{abstract}
The present study provides evidence that activated spleen lymphocytes from Walker 256 tumor bearing rats are more susceptible than controls to tert-butyl hydroperoxide (t-BOOH)-induced necrotic cell death in vitro. The iron chelator and antioxidant deferoxamine, the intracellular $\mathrm{Ca}^{2+}$ chelator BAPTA, the L-type $\mathrm{Ca}^{2+}$ channel antagonist nifedipine or the mitochondrial permeability transition inhibitor cyclosporin A, but not the calcineurin inhibitor FK-506, render control and activated lymphocytes equally resistant to the toxic effects of t-BOOH. Incubation of activated lymphocytes in the presence of $\mathrm{t}-\mathrm{BOOH}$ resulted in a cyclosporin A-sensitive decrease in mitochondrial membrane potential. These results indicate that the higher cytosolic $\mathrm{Ca}^{2+}$ level in activated lymphocytes increases their susceptibility to oxidative stress-induced cell death in a mechanism involving the participation of mitochondrial permeability transition.
\end{abstract}

Key words: cell death, free radicals, immune response, lymphopenia, mitochondrial permeability transition, spleen lymphocyte.

\section{INTRODUCTION}

Lymphocyte activation is an essential step in the immune response that generally occurs during tumor development; it requires T-cell recognition of specific tumor antigens through the interaction of the lymphocyte receptor with the major histocompatibility complex of antigen-presenting cells (Hermiston et al. 2002, Roy 2003, Grossman et al. 2004). Elevations in cytosolic $\mathrm{Ca}^{2+}$ concentration $\left(\left[\mathrm{Ca}^{2+}\right]_{\text {cyt }}\right)$ and reactive oxygen species (ROS) production are characteristically observed in such activated lymphocytes, and are important factors associated with either a high rate of cell proliferation or mechanisms that lead to cell death (Buttke and Sandstrom 1995, Williams and Kwon 2004, Feske 2007). It is proposed that a high expression of anti-apoptotic factors, including interleukin-2, mitochondrial uncoupling

\footnotetext{
*Member Academia Brasileira de Ciências

Correspondence to: Anibal E. Vercesi

E-mail: anibal@unicamp.br
}

protein-2, and members of the Bcl-2 family, increases the resistance of activated lymphocytes to cell death, pushing the cell towards proliferation (Quintana et al. 2005, Arnold et al. 2006, Degasperi et al. 2006a, Krammer et al. 2007).

In the present study, the effects of the tert-butyl hydroperoxide $(\mathrm{t}-\mathrm{BOOH})$, a well known prooxidant, were evaluated on proliferation and death of activated spleen lymphocytes from Walker 256 tumor bearing (TB) rats (Quintana et al. 2005, Degasperi et al. 2006a, b) and lymphocytes from control (CT) rats. t-BOOH induces oxidative stress by exhausting cellular GSH and NADPH, substrates of the antioxidant enzymes glutathione peroxidase and glutathione reductase, respectively, thus favoring the accumulation of $\mathrm{H}_{2} \mathrm{O}_{2}$ (Jocelyn and Dickson 1980, Bernardes et al. 1986, Castilho et al. 1995). In addition, t-BOOH promotes a $\mathrm{Ca}^{2+}$-stimulated generation of methyl, $t$-butoxyl, and $t$-butylperoxyl radicals (Kennedy et al. 1992, Castilho et al. 1995). Previous 
results from our group indicated that the enhanced and continuous production of ROS by mitochondria treated with $\mathrm{Ca}^{2+}$ plus t-BOOH leads to a form of non-selective permeabilization of the inner mitochondrial membrane know as the mitochondrial permeability transition (MPT) (Castilho et al. 1995, Kowaltowski et al. 2001).

The results presented here demonstrate that activated TB rat lymphocytes are more susceptible to necrotic death induced by $\mathrm{t}$-BOOH-mediated oxidative stress than are control cells.

\section{MATERIALS AND METHODS}

\section{Chemicals}

The tert-butyl hydroperoxide ( $\mathrm{t}-\mathrm{BOOH})$, carbonyl cyanide m-chloro phenyl hydrazone (CCCP), cyclosporin A (CsA), oligomycin, deferoxamine, nifedipine and propidium iodide (PI) were obtained from Sigma (St. Louis, MO, USA). BAPTA-AM (1,2-bis(2-aminophenoxy) ethane $\mathrm{N}, \mathrm{N}, \mathrm{N}^{\prime}, \mathrm{N}^{\prime}$-tetraacetic acid, tetraacetoxymethyl ester), 3,3'-dihexyloxacarbocyanine iodide $\left(\operatorname{DioC}_{6}(3)\right)$, Fluo-3AM and Pluronic acid F-127 were purchased from Molecular Probes Inc. (Eugene, OR, USA). FicollPaque $^{\mathrm{TM}}$ PLUS was obtained from Becton Dickinson Biosciences (San Jose, CA, USA), RPMI 1640 (Roswell park medium) from Cultlab (Campinas, Brazil), and FK-506 from LC Laboratories (Woburn, MA, USA). Annexin $\mathrm{V}$ was purchased from the Laboratory of Immunobiology of the University of São Paulo (São Paulo, Brazil). All other chemicals were standard commercial products of reagent-grade quality.

\section{ANIMAL TREATMENT}

Nine-week-old male Wistar rats (Rattus novergicus albinos) were obtained from the UNICAMP Central Animal Breeding Center. Rats were kept under standard laboratory conditions $\left(20-22^{\circ} \mathrm{C}\right.$ and $12 \mathrm{~h} / 12 \mathrm{~h}$ light/dark cycle) with free access to a standard diet (Labina/Purina, Campinas, SP, Brazil) and tap water. Animal experiments followed the University guidelines for the use of animals in experimental studies (protocol no. 487-1, approved by the UNICAMP Ethics Committee in 2002) and followed the Guide for the Care and Use of Laboratory Animals published by the US National Institute of Health (NIH publication no. 85-23, revised in 1996).

The Walker 256 tumor cell line (originally obtained from the Christ Hospital Line, National Cancer Institute Bank, Cambridge, USA) is kept frozen in liquid nitrogen. For experimental procedures, Walker 256 cells were maintained by consecutive intraperitoneal inoculums, each with $20 \times 10^{6}$ tumor cells in phosphatebuffered saline solution (PBS). Walker 256 tumor cells with viability $>98 \%$ isolated from the ascitic fluid were used for intraperitoneal inoculums, with viability estimated by the trypan blue exclusion method.

\section{SPLEEN LyMPHOCYTE ISOLATION}

Rat spleens were gently homogenized in a manual Dounce homogenizer. Spleen homogenates were overlaid onto a Ficoll-Paque ${ }^{\mathrm{TM}}$ PLUS layer, with density adjusted to $1.076 \mathrm{~g} / \mathrm{ml}$, and centrifuged at $1000 \mathrm{~g}$ at room temperature for $25 \mathrm{~min}$. The interface cell layer containing lymphomonocytes was recovered by Pasteur pipette, washed twice in PBS, and centrifuged at $500 \mathrm{~g}$ for $10 \mathrm{~min}$ (Boyum 1976, Degasperi et al. 2006a, b). Cells were counted in a Neubauer chamber, and cell viability was determined by the trypan blue exclusion method. Cells were only used when viability was greater than $98 \%$.

\section{Cell Culture and Treatments}

The in vitro lymphocyte cultures were obtained by seeding isolated spleen lymphocytes at an initial density of $10^{6}$ cells $/ \mathrm{ml}$ in RPMI 1640 in $1.5 \mathrm{~cm}^{2}$ plate wells in a humidified atmosphere $\left(5 \% \mathrm{CO}_{2}\right.$ at $\left.37^{\circ} \mathrm{C}\right)$. After $1 \mathrm{~h}$, lymphocytes from $\mathrm{TB}$ rats showed a more rapid growth rate than those of the $\mathrm{CT}$ rats. At this time, the TB rat lymphocytes were again counted and diluted to $10^{6}$ cells/ml in RPMI 1640. CT and TB rat lymphocytes were than treated with $\mathrm{t}-\mathrm{BOOH}$ in the presence of deferoxamine, nifedipine, cyclosporin A or FK-506, as indicated in the figure legends.

For BAPTA loading, the lymphocytes were preincubated with $20 \mu \mathrm{M}$ BAPTA-AM, after $1 \mathrm{~h}$, the lymphocytes were washed, counted and diluted to $10^{6}$ cells/ $\mathrm{ml}$ in RPMI 1640. BAPTA-loaded CT and TB rat lymphocytes were than incubated under control conditions or treated with t-BOOH for up to $4 \mathrm{~h}$.

\section{FLOW CYTOMETRY}

The samples (isolated CT and TB rat spleen lymphocytes) were analyzed in a FACSCalibur flow cytome- 
ter equipped with an argon laser and CellQuest software (Becton Dickinson, San Jose, CA, USA). Ten thousand events were acquired from each sample. The lymphocyte populations were identified by their light-scattering characteristics, enclosed in electronic gates, and analyzed for intensity of the fluorescent probe signal (Degasperi et al. 2006a).

\section{Analysis of Cell Viability By ANNEXin-V AND PI STAINING}

Lymphocytes were labelled with annexin-V following the manufacturer's instructions (Brumatti et al. 2003). Briefly, $10^{6}$ cells were harvested at each point in time, washed twice with PBS and resuspended in a binding buffer containing annexin V-FITC (1:500). After 20 min of incubation at room temperature, the lymphocytes were centrifuged at $1000 \mathrm{~g}$ for $5 \mathrm{~min}$ and resuspended in binding buffer containing PI (1:50). Quantitative determinations of apoptotic and necrotic cells were carried out as previously described (Martin et al. 1995).

\section{Measurement of Cytosolic Free $\mathrm{CA}^{2+}$ CONCENTRATIONS}

Cytosolic free $\mathrm{Ca}^{2+}$ concentrations $\left(\left[\mathrm{Ca}^{2+}\right]_{\text {cyt }}\right)$ were monitored with the green fluorescent probe Fluo-3AM $(5 \mu \mathrm{M})$, a single wavelength indicator, by flow cytometry. Spleen lymphocytes $\left(10^{6}\right.$ cells $\left./ \mathrm{mL}\right)$ in RPMI 1640 medium were loaded with $5 \mu \mathrm{M}$ Fluo-3AM containing $1 \mu \mathrm{M}$ pluronic acid $\mathrm{F}-127$ (for proper dispersal) and $30 \mu \mathrm{g} / \mathrm{mL}$ BSA in a humified $\mathrm{CO}_{2}$ incubator $\left(5 \% \mathrm{CO}_{2}\right)$ at $37^{\circ} \mathrm{C}$ for $40 \mathrm{~min}$. Nonhydrolyzed Fluo-3 AM was removed by washing the cells with medium just before fluorescence acquisition. Calibration was performed at the end of each experiment. $\left[\mathrm{Ca}^{2+}\right]_{\mathrm{cyt}}$ was calculated considering $\mathrm{K}_{\mathrm{d}}$ of the $\mathrm{Ca}^{2+}$-Fluo-3 complex $390 \mathrm{nM}$ (Mather and Rottenberg 2002).

\section{Determination of Mitochondrial Membrane Electrical Potential $\left(\Delta \Psi_{m}\right)$ Using Flow CYTOMETRY}

After experimental incubation, lymphocytes $\left(10^{6}\right.$ cells/ $\mathrm{ml}$ ) were washed in PBS buffer and incubated with $0.2 \mathrm{nM} \mathrm{DioC}_{6}(3)$ in $400 \mu \mathrm{l}$ of RPMI 1640 medium for $30 \mathrm{~min}$ at $37^{\circ} \mathrm{C}$ in a humidified $\mathrm{CO}_{2}$ incubator $(5 \%$ $\left.\mathrm{CO}_{2}\right)$. One half of each cell sample $(200 \mu \mathrm{l})$ was separated into a new tube, with the addition of $50 \mu \mathrm{M} \mathrm{CCCP} \mathrm{a}$ protonophore that dissipates $\Delta \Psi_{m}$ (Rottenberg and Wu 1998, Campos et al. 2004). Both samples were incubated for a further 30 minutes. Oligomycin $(1 \mu \mathrm{g} / \mathrm{ml})$ was added during the last $10 \mathrm{~min}$ prior to FACS analysis, as indicated in the figure. In non-saturated concentrations, $\operatorname{DioC}_{6}(3)$ binds preferentially to mitochondria, since electrical potential of the mitochondrial $\left(\Delta \Psi_{m}\right)$ is much higher $(-180 \mathrm{mV})$ than that of the plasma membrane $(-60 \mathrm{mV})$. Results were normalized using the $\mathrm{F} / \mathrm{F}_{\mathrm{CCCP}}$ ratio, where $\mathrm{F}$ is the mean fluorescence intensity of $\operatorname{DioC}_{6}(3)$ (maximum fluorescence) and $\mathrm{F}_{\mathrm{CCCP}}$ is the mean fluorescence in the presence of CCCP (minimum fluorescence).

STATISTICAL ANALYSiS

Three independent experiments were performed, each in triplicate, with results displayed as average $\pm \mathrm{SD}$; significance was assessed by ANOVA and a post-hoc Tukey test. The results of cell viability estimated by annexin- $\mathrm{V}$ and propidium iodide staining were analysed by a Mann-Whitney U test. Level of significance was set at $\mathrm{p}<0.05$ using SAS software (Statistical Analysis System 6.12/SAS Institute Inc, 1989-1996, Cary, NC, USA).

\section{RESULTS}

High Susceptibility of ACtivated Lymphocytes to T-BOOH-INDUCED CELl DEATH

The experiments presented in Figure 1A show that TB rat lymphocytes exhibited a higher rate of proliferation than did CT rat lymphocytes, although the presence of $\mathrm{t}$ $\mathrm{BOOH}$ decreased the rate of proliferation, especially for the TB rat lymphocytes. The susceptibility of CT and TB rat lymphocytes to t-BOOH was also analyzed as the percentage of viable cells considering their respective controls at each time point (Fig. 1B). After $4 \mathrm{~h}$ of incubation in the presence of $\mathrm{t}-\mathrm{BOOH}$ the percentage of viable cells was reduced to nearly $20 \%$ for TB rat lymphocytes whereas $60 \%$ of CT rat lymphocytes continued viable (Fig. 1B). The decrease in rate of proliferation for both cell types upon t-BOOH treatment was accompanied by an increase in the number of trypan blue-positive cells (Fig. 1C), with the number of dead cells in TB rat lymphocytes being more than double that of the control lymphocytes. Furthermore, in the presence of $\mathrm{t}-\mathrm{BOOH}$ the number of lymphocytes positive to propidium iodide 

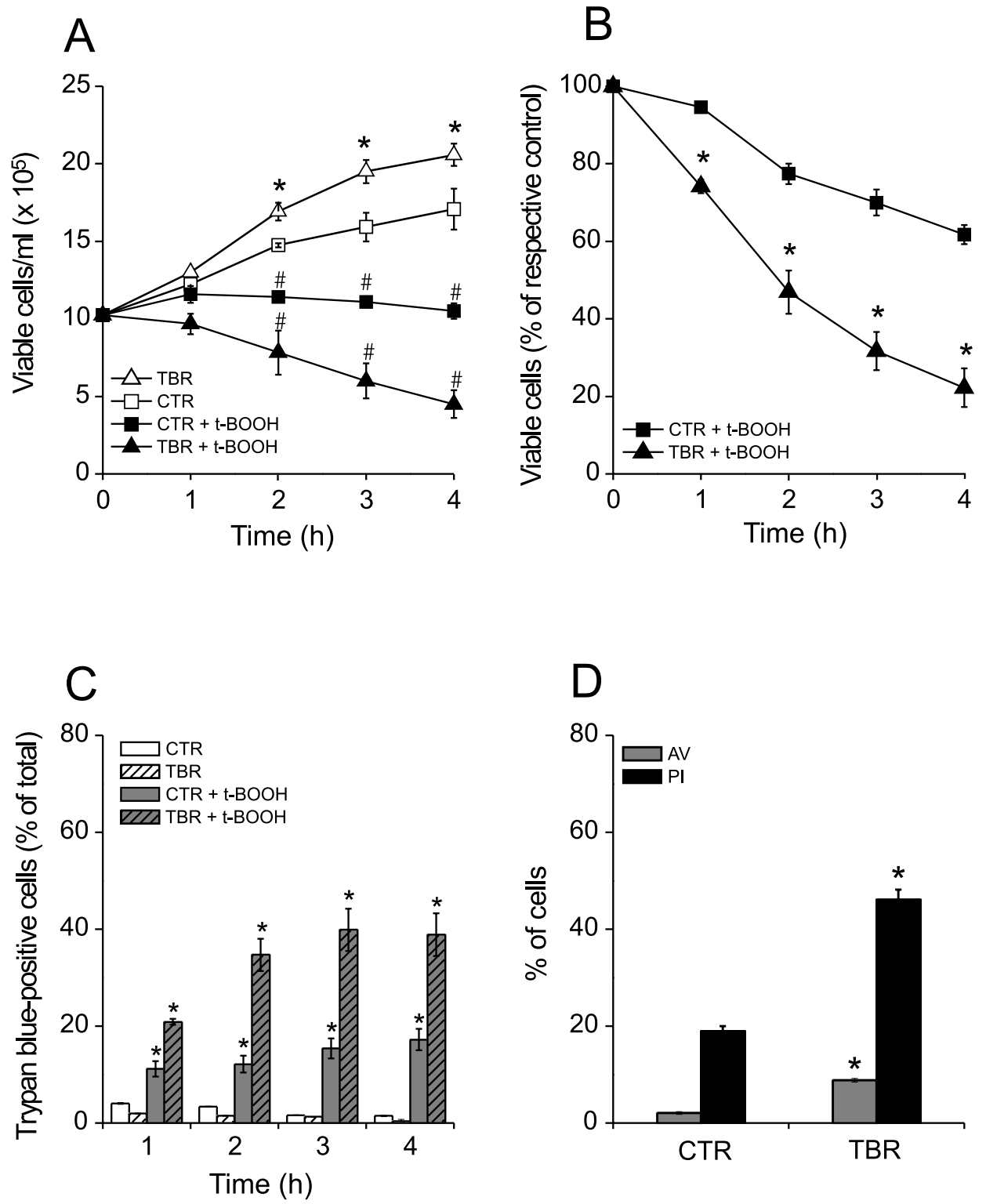

Fig. 1 - Increased susceptibility to t-BOOH-induced necrotic cell death of lymphocytes from tumor bearing rats (TBR) over that of control rats (CTR). (A) Lymphocytes were incubated for $4 \mathrm{~h}$ in the absence of $500 \mu \mathrm{M}$ t-BOOH ( $\square$ : CTR; $\triangle$ : TBR) or in its presence $(\boldsymbol{\square}: \mathrm{CTR}+\mathrm{t}-\mathrm{BOOH} ; \boldsymbol{\Lambda}$ $\mathrm{TBR}+\mathrm{t}-\mathrm{BOOH}) .{ }^{*} \mathrm{p}<0.05 v s$. CTR without $\mathrm{t}-\mathrm{BOOH} ;{ }^{*} \mathrm{p}<0.05 v s$. respective group without t-BOOH. (B) Effect of t-BOOH on the percentage of viable cells considering their respective controls at each time point $(\mathbf{\square}: \mathrm{CTR}+\mathrm{t}-\mathrm{BOOH} ; \mathbf{\Delta}: \mathrm{TBR}+\mathrm{t}-\mathrm{BOOH}) .{ }^{*} \mathrm{p}<0.05 v s$. CTR $+\mathrm{t}-\mathrm{BOOH}$. (C) Death of lymphocytes in the absence of $500 \mu \mathrm{M}$ t-BOOH (CTR: white bars; TBR: white hatched bars) or in its presence (CTR $+\mathrm{t}-\mathrm{BOOH}$ : gray bars; TBR + t-BOOH: gray hatched bars). Viability was estimated by the trypan blue exclusion method repeated hourly for $4 \mathrm{~h} .{ }^{*} \mathrm{p}<0.05$ vs. respective group without t-BOOH. (D) Determination of apoptotic and necrotic death of lymphocytes incubated in the presence of t-BOOH. After $4 \mathrm{~h}$, samples of $10^{6}$ cells $/ \mathrm{ml}$ were annexin V-FITC labeled (AV; gray bars) and propidium iodide stained (PI; black bars) and then analyzed by flow cytometry. ${ }^{*} \mathrm{p}<0.05$ vs. respective CTR. 

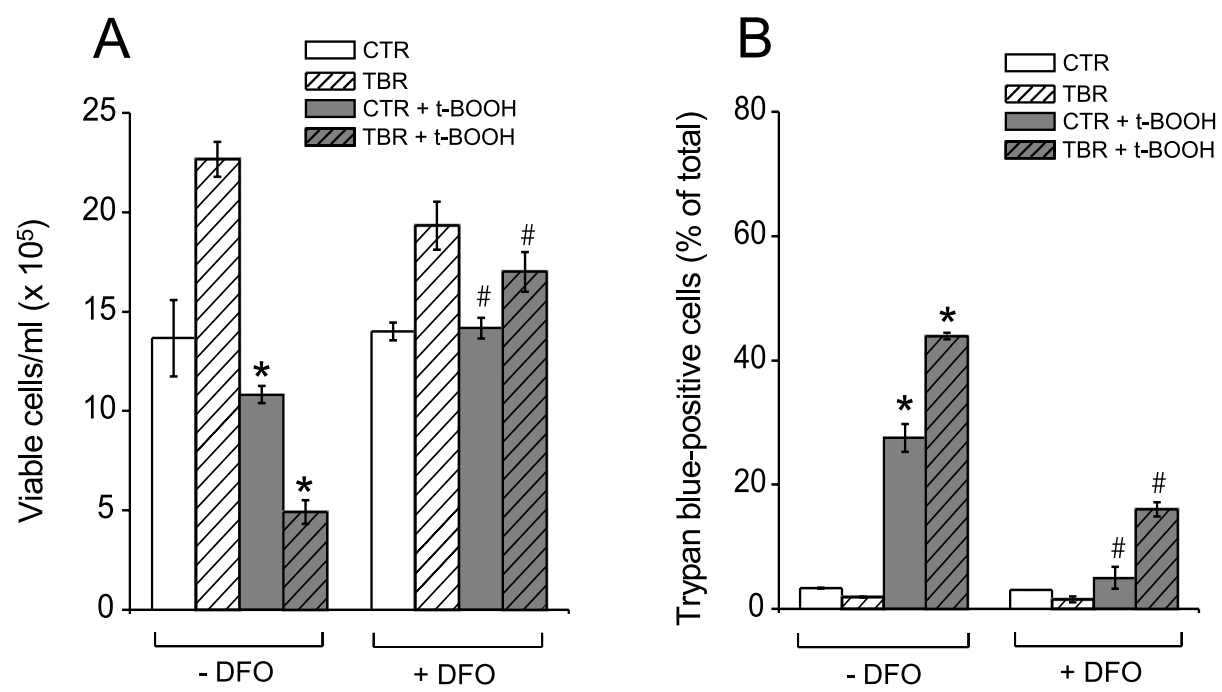

Fig. 2 - t-BOOH-induced death of CTR and TBR lymphocytes is prevented by deferoxamine (DFO). (A) Growth of DFO-treated CTR (white and gray bars) and TBR lymphocytes (white hatched and gray hatched bars) incubated for $4 \mathrm{~h}$ in the absence of $500 \mu \mathrm{M} \mathrm{t}-\mathrm{BOOH}$ (white and white hatched bars) or in its presence (gray and gray hatched bars). (B) Death of DFO-treated CTR and TBR lymphocytes incubated for $4 \mathrm{~h}$ in the absence of $500 \mu \mathrm{M}$ t-BOOH or in its presence. ${ }^{*} \mathrm{p}<0.05 v s$. respective group without $\mathrm{t}-\mathrm{BOOH}$ in the absence of DFO. ${ }^{\#} \mathrm{p}<0.05 v s$. respective group treated with $\mathrm{t}-\mathrm{BOOH}$ in the absence of DFO.

was much larger than that of those positive to annexin- $\mathrm{V}$ (Fig. 1D), indicating that cell death under these conditions was predominantly necrotic.

T-BOOH-Induced Lymphocyte Death is Prevented BY DEFEROXAMINe

The involvement of oxidative stress in the process of $t$ BOOH-induced spleen lymphocyte death was assessed in vitro, by testing the effect of deferoxamine on cell proliferation and viability (Fig. 2). In the presence of this antioxidant/iron chelator (Halliwell 1989, Bartesaghi et al. 2004), t-BOOH did not significantly decrease the proliferation rate of $\mathrm{CT}$ and $\mathrm{TB}$ rat lymphocytes (Fig. 2A). Moreover, deferoxamine decreased at least 2.5-fold the number of trypan blue-positive cells after $4 \mathrm{~h}$ of incubation in the presence of t-BOOH (Fig. 2B) indicating that lymphocyte death under these conditions is mediated by oxidative stress.

INCREASED SUSCEPTIBILITY OF TB RAT LYMPHOCYTES TO T-BOOH-INDUCED DEATH IS MEdiated BY $\mathrm{HIGH}\left[\mathrm{CA}^{2+}\right]_{\mathrm{CYT}}$

The experiments presented in Figure 3 show that $\left[\mathrm{Ca}^{2+}\right]_{\mathrm{cyt}}$ in TB rat spleen lymphocytes is at least double that of CT rat lymphocytes when both cells were incubated during $3 \mathrm{~h}$ in RPMI 1640 medium. When lymphocytes were incubated in a medium containing $10 \mu \mathrm{M}$ nifedipine, a L-type $\mathrm{Ca}^{2+}$ channel antagonist, no such significant difference in $\left[\mathrm{Ca}^{2+}\right]_{\text {cyt }}$ was observed.

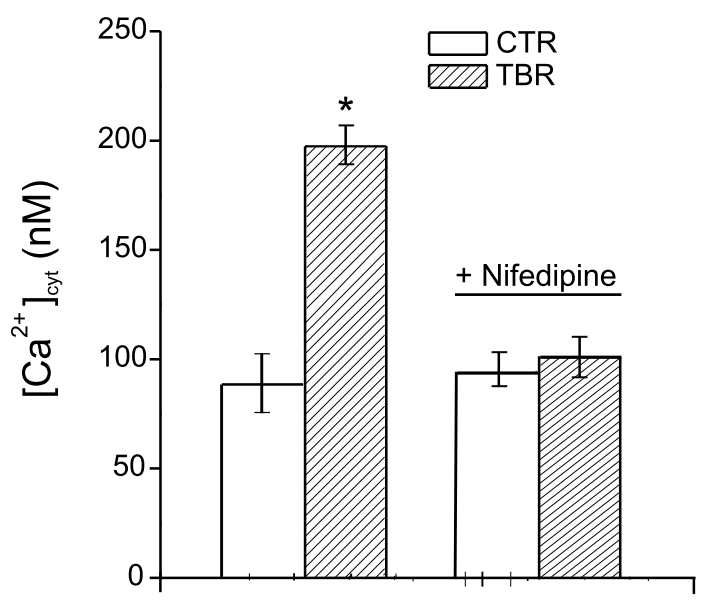

Fig. 3 - The increase in cytosolic free $\mathrm{Ca}^{2+}$ concentration $\left(\left[\mathrm{Ca}^{2+}\right]_{\text {cyt }}\right)$ in TBR lymphocytes is prevented by nifedipine. CTR (white bars) and TBR lymphocytes (hatched bars) were incubated for $3 \mathrm{~h}$ in RPMI 1640 medium in the absence or presence of $10 \mu \mathrm{M}$ nifedipine as indicated in the figure. ${ }^{*} \mathrm{p}<0.01$ vs. CTR. 
t-BOOH-induced death of $\mathrm{CT}$ and $\mathrm{TB}$ rat lymphocytes incubated in the presence of nifedipine (Fig. 4) or loaded with the $\mathrm{Ca}^{2+}$ chelator BAPTA (Fig. 5) was also investigated. The cytoprotective effects of nifedipine and BAPTA were similar to those obtained with deferoxamine. Thus, these findings indicate that $\left[\mathrm{Ca}^{2+}\right]_{\text {cyt }}$ plays an important role in the higher susceptibility of TB rat lymphocytes to t-BOOH.

\section{T-BOOH-INDUCED LYMPHOCYTE NECROSIS IS MEdiated By MPT}

Both cyclosporin A and FK-506 inhibit calcineurin, but only cyclosporin A inhibits MPT (Crompton et al. 1988, Griffiths and Halestrap 1991, Galat 2003). Here, the presence of cyclosporin A (Figs. 6A-C) almost completely prevented the decrease in cell proliferation and viability, as well as the increase in the number of trypan blue-positive cells induced by t-BOOH. A possible decrease in cell proliferation by the immunosuppressant drug cyclosporin A was not observed probably because the activated lymphocytes already contained high levels of IL-2 during the time course of our experiments. In contrast, protective effects were not observed in the presence of FK-506 (Figs. 6D-F). Moreover, the results shown in Figure 7 indicate that incubation in the presence of t-BOOH for $4 \mathrm{~h}$ induces a decrease in $\Delta \Psi_{\mathrm{m}}$ especially in TB rat lymphocytes. CT rat lymphocytes treated with $\mathrm{t}-\mathrm{BOOH}$ showed only a $\sim 20 \%$ decrease in the $\mathrm{F} / \mathrm{F}_{\mathrm{cccp}}$ ratio during this incubation time (results not shown). The t-BOOH-induced decrease in $\Delta \Psi_{\mathrm{m}}$ was prevented by simultaneous incubation in the presence of cyclosporin A plus oligomycin, but not in that of oligomycin alone, supporting the notion that $\mathrm{t}-\mathrm{BOOH}$ promotes MPT in these cells.

\section{DISCUSSION}

The present study analyses the effects of $\mathrm{t}-\mathrm{BOOH}$ on the proliferation and death of lymphocytes obtained from TB and CT rats. The TB rat lymphocytes have been activated as seen by the presence of high levels of interleukin 2 (IL-2) (Degasperi et al. 2006a). Cell proliferation was stimulated doubling the number of activated lymphocytes in four hours (Fig. 1A). The activated TB rat lymphocytes overexpress the anti-apoptotic protein Bcl2 and mitochondrial uncoupling protein-2 (Degasperi et al. 2006a) which protects the cells by preventing the conversion of high levels of ROS and $\left[\mathrm{Ca}^{2+}\right]_{\text {cyt }}$ into a pathway leading to mitochondrial dysfunction and cell death. Despite the protective effect of these proteins, TB rat lymphocytes display a higher susceptibility to cell death induced by $\mathrm{t}-\mathrm{BOOH}$ than do the control cells (Fig. 8). t-BOOH induces oxidative stress by exhausting cellular GSH and NADPH, and promotes a $\mathrm{Ca}^{2+}$-stimulated generation of methyl, $t$-butoxyl, and $t$-butylperoxyl radicals as detected by electron paramagnetic resonance (EPR) signals (Kennedy et al. 1992, Castilho et al. 1995). Both nifedipine or BAPTA, that decrease $\left[\mathrm{Ca}^{2+}\right]_{\text {cyt }}$ of control and activated lymphocytes render them equally resistant to the toxic effects of $\mathrm{t}-\mathrm{BOOH}$. This indicates that the higher $\left[\mathrm{Ca}^{2+}\right]_{\text {cyt }}$ in activated lymphocytes renders these cells more susceptible to exogenous prooxidants.

Although both cyclosporin A and FK-506 inhibit the activity of peptidylprolyl cis/trans isomerases or imunophilins, only cyclosporin A is an inhibitor of MPT (Crompton et al. 1988, Griffiths and Halestrap 1991, Friberg et al. 1998, Galat 2003). Therefore, the reduction in t-BOOH-induced necrotic lymphocyte death by cyclosporin A, but not by FK-506, indicates that MPT is involved in the mechanism of cell death and excludes activation of the calcineurin pathway. Inner membrane permeabilization caused by MPT results in loss of matrix components, impairment of mitochondrial function and substantial mitochondrial swelling, with consequent outer membrane rupture and release of pro-apoptotic mitochondrial proteins (Zoratti and Szabo 1995, Green and Reed 1998, Lemasters et al. 1998, Crompton 1999, Kowaltowski et al. 2001, Green and Kroemer 2004). As a result, MPT actively participates in events that initiate either necrotic or apoptotic cell death.

The protection conferred by deferoxamine against $\mathrm{t}-\mathrm{BOOH}$-induced lymphocyte death indicates the participation of ROS under these conditions. Deferoxamine, approved by FDA for the removal of iron in conditions involving iron overload, such as $\beta$-thalassemia (Giardini et al. 1993), has been used primarily as a metal chelating agent to block the iron-dependent hydroxyl radical (Goldstein and Czapski 1990). It may involve an additional or alternative antioxidant mechanism which would directly scavenge free radicals, such as superoxides $\left(\mathrm{O}_{2}^{-}\right)$ (Goldstein and Czapski 1990), hydroxyls ( $\cdot \mathrm{OH})$ (Hoe et 

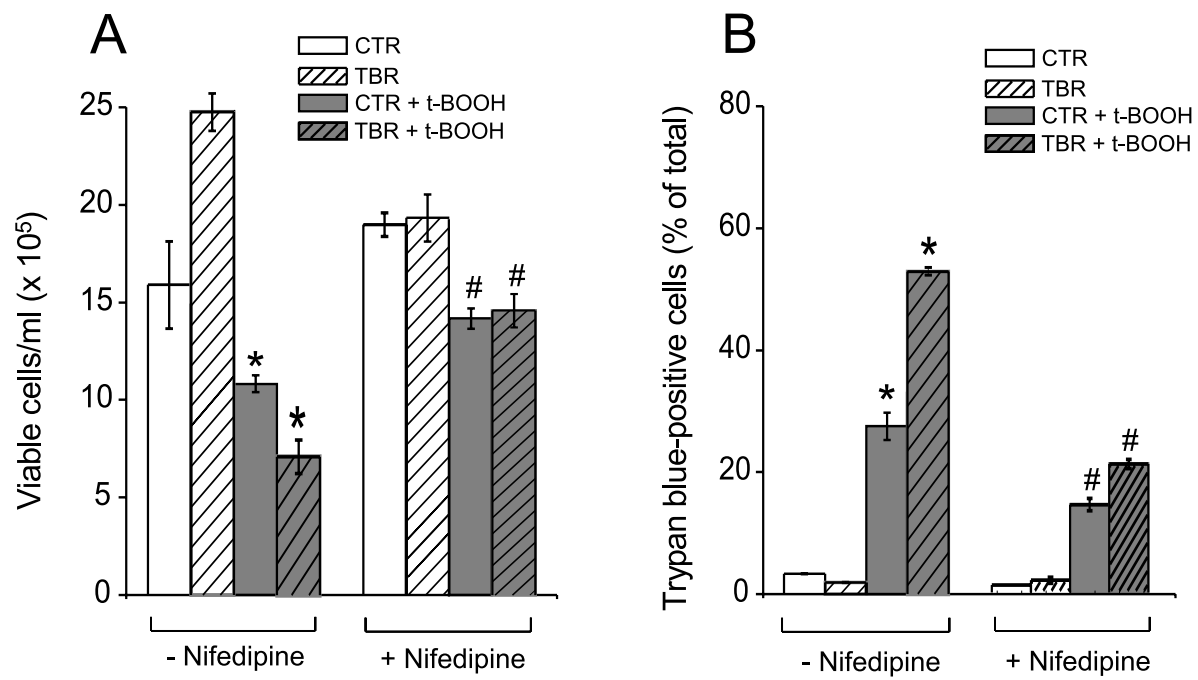

Fig. 4 -t-BOOH-induced death of CTR and TBR lymphocytes is prevented by nifedipine. (A) Growth of nifedipine-treated CTR (white and gray bars) and TBR lymphocytes (white hatched and gray hatched bars) incubated for $4 \mathrm{~h}$ in the absence of $500 \mu \mathrm{M} \mathrm{t}-\mathrm{BOOH}$ (white and white hatched bars) or in its presence (gray and gray hatched bars). (B) Death of nifedipine-treated CTR and TBR lymphocytes incubated for $4 \mathrm{~h}$ in the absence of $500 \mu \mathrm{M}$ t-BOOH or in its presence. ${ }^{*} \mathrm{p}<0.05 \mathrm{vs}$ respective group without $\mathrm{t}-\mathrm{BOOH}$ in the absence of nifedipine. ${ }^{\#} \mathrm{p}<0.05 v s$. respective group treated with $\mathrm{t}-\mathrm{BOOH}$ in the absence of nifedipine.
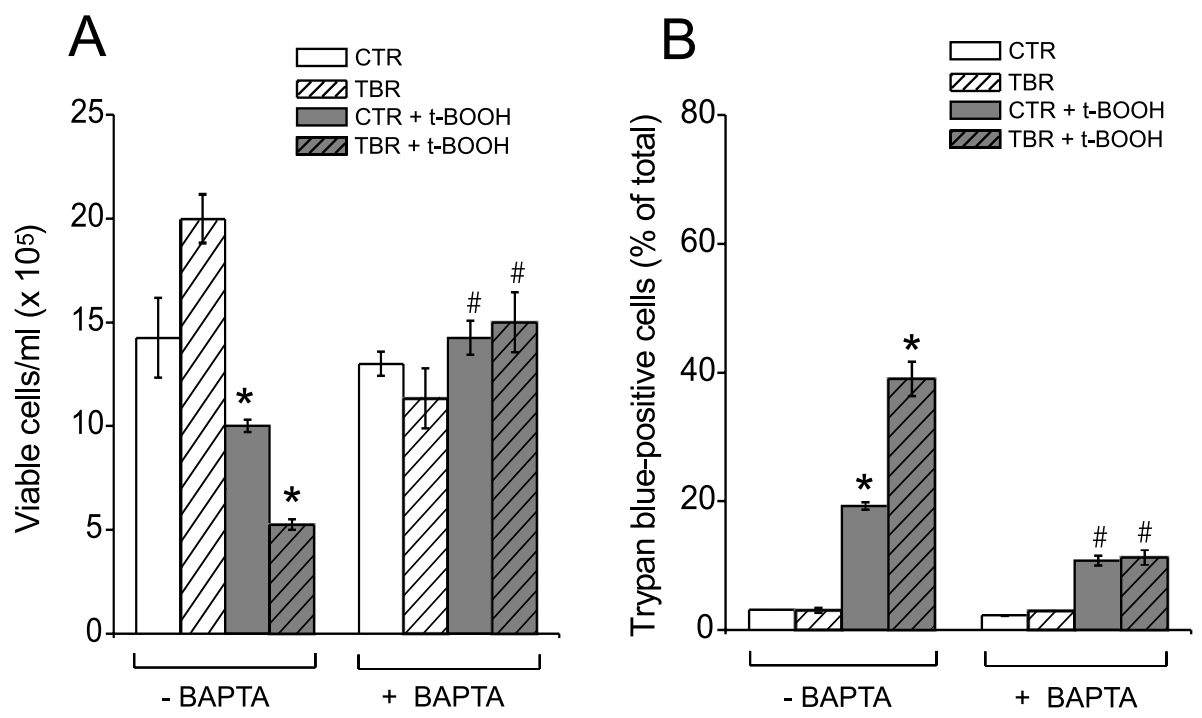

Fig. 5 - t-BOOH-induced death of CTR and TBR lymphocytes is prevented by intracellular $\mathrm{Ca}^{2+}$ chelation. (A) Growth of BAPTA-loaded CTR (white and gray bars) and TBR lymphocytes (white hatched and gray hatched bars) incubated for $4 \mathrm{~h}$ in the absence of $500 \mu \mathrm{M} \mathrm{t}-\mathrm{BOOH}$ (white and white hatched bars) or in its presence (gray and gray hatched bars). (B) Death of BAPTA-loaded CTR and TBR lymphocytes incubated for 4 $\mathrm{h}$ in the presence of $500 \mu \mathrm{M} \mathrm{t}-\mathrm{BOOH}$ or in its absence. ${ }^{*} \mathrm{p}<0.05 v s$. respective group without t-BOOH, in the absence of BAPTA. ${ }^{\#} \mathrm{p}<0.05 v s$. respective group treated with $\mathrm{t}-\mathrm{BOOH}$, in the absence of BAPTA.

al. 1982), peroxyls (Hartley et al. 1990), peroxynitritederived carbonate species $\left(\mathrm{CO}_{3}^{-}\right)$or nitrogen dioxide $\left(\cdot \mathrm{NO}_{2}\right)$ radicals (Bartesaghi et al. 2004). Indeed, it is known that under conditions of t-BOOH-mediated oxidative stress deferoxamine inhibits death of hepatocytes (Nieminen et al. 1997), thymocytes (Bartoli et al. 1994), 


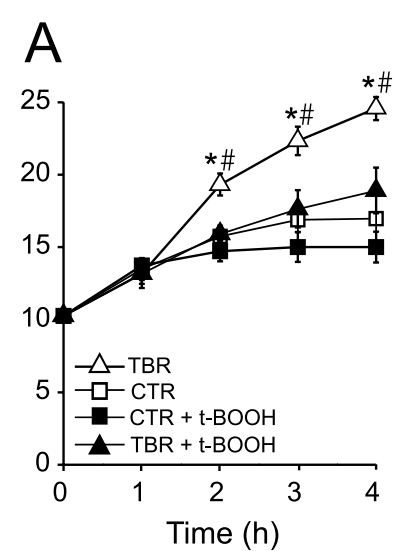

B
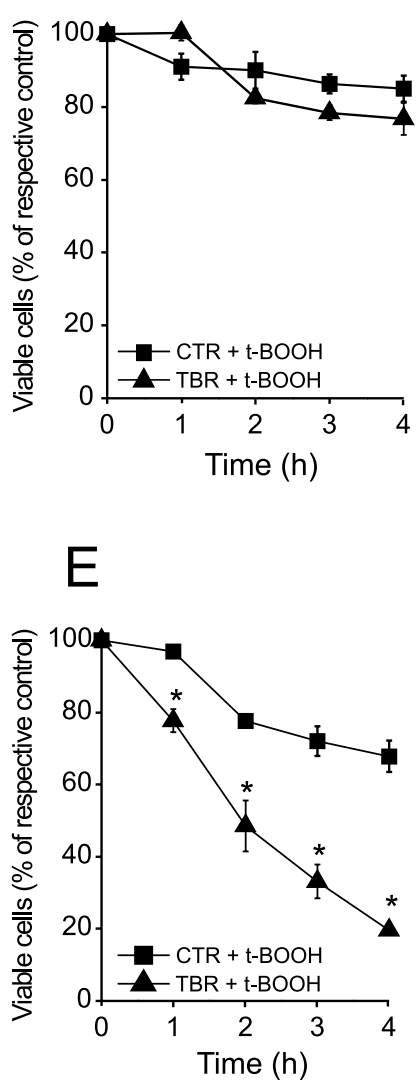

C

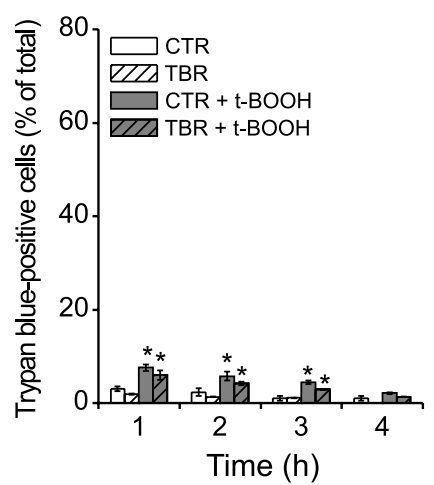

$\mathrm{F}$

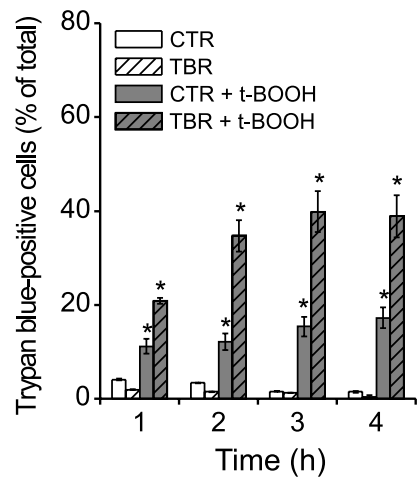

Fig. 6 - t-BOOH-induced lymphocyte cell death is prevented by cyclosporin A. (A; D) CTR and TBR lymphocytes were incubated for $4 \mathrm{~h}$ in the presence of $1 \mu \mathrm{M}$ cyclosporin A (A) or $0.5 \mu \mathrm{M}$ FK-506 (D) without other additions ( $\square$ : CTR; $\triangle$ : TBR) or with $500 \mu \mathrm{M} \mathrm{t}-\mathrm{BOOH}$ (目: CTR + t-BOOH; $\mathbf{\Lambda}:$ TBR $+\mathrm{t}-\mathrm{BOOH}) .{ }^{*} \mathrm{p}<0.05$ vs. CTR without t-BOOH; ${ }^{\#} \mathrm{p}<0.05$ vs. respective group with t-BOOH. (B; E) Effect of t-BOOH on the percentage of viable cells considering their respective controls at each time point when the incubations were conducted in the presence of $1 \mu \mathrm{M}$ cyclosporin A (B) or $0.5 \mu \mathrm{M}$ FK-506 (E) (目: CTR + t-BOOH; $\mathbf{\Delta}$ : TBR $+\mathrm{t}-\mathrm{BOOH}) .{ }^{*} \mathrm{p}<0.05 v s$. CTR $+\mathrm{t}-\mathrm{BOOH}$. (C; F) Death of CTR and TBR lymphocytes incubated with $1 \mu \mathrm{M}$ cyclosporin A (C) or $0.5 \mu \mathrm{M}$ FK-506 (F), in the absence of $500 \mu \mathrm{M}$ t-BOOH (CTR: open bars; TBR: open hatched bars) or in its presence (CTR: gray bars; TBR: gray hatched bars). Viability was estimated by the trypan blue exclusion method repeated hourly for $4 \mathrm{~h} .{ }^{*} \mathrm{p}<0.05 v s$. respective group without t-BOOH.

neurons and astrocytes (Abe and Saito 1998) or cardiac myocytes (Daly et al. 1991).

These results indicate that activated lymphocytes are more susceptible to oxidative stress-induced death than are controls. This observation may help the understanding of the mechanisms underlying activated lymphocytes death in vivo in patients treated by the anthracyclines doxorubicin or daunorubicin. The lymphopenia caused by these antineoplastic agents is associated with increased susceptibility to opportunistic infections (Mackall et al. 1994, Sthanke et al. 2001). In addition to interacting with DNA, these compounds also give rise to ROS, since they undergo intracellular redox-cycling (Doroshow 1983, Wallace 2003, Conklin 2004). Therefore, it seems that activated lymphocytes would be more susceptible to death caused by antineoplastic agents such as anthracyclines, alkylating agents, or camptothecins (Conklin 2004).

In conclusion, the present study has demonstrated that activated lymphocytes from Walker 256 tumor-bearing rats are more susceptible to in vitro $\mathrm{t}-\mathrm{BOOH}$-mediated oxidative stress than are control cells. This cytotox- 


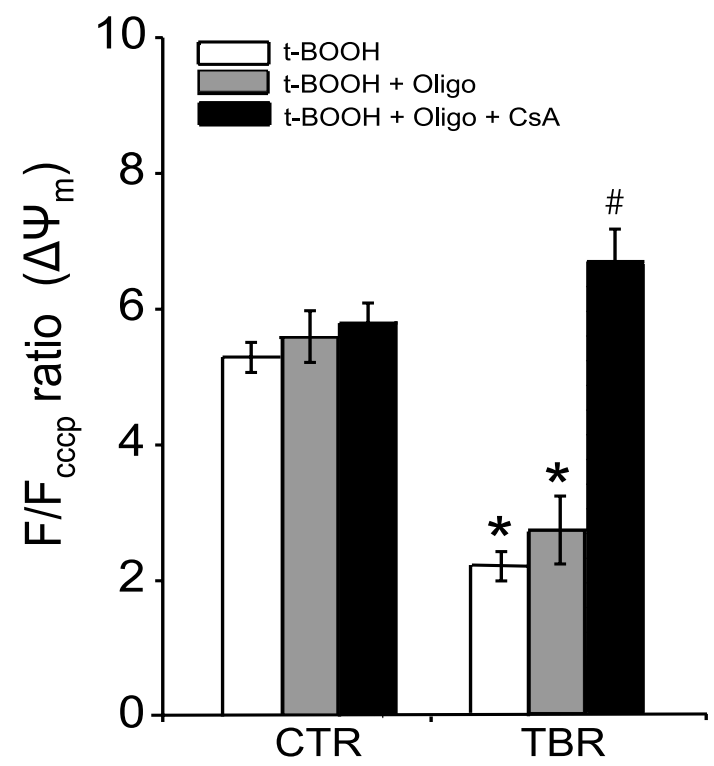

Fig. 7 - Mitochondrial permeability transition mediates t-BOOH-induced $\Delta \Psi_{\mathrm{m}}$ decrease in TBR lymphocytes. $\Delta \Psi_{\mathrm{m}}$ in CTR and TBR lymphocytes $\left(10^{6} \mathrm{cells} / \mathrm{ml}\right)$ was determined after $4 \mathrm{~h}$ incubation in the presence of $500 \mu \mathrm{M} \mathrm{t}$-BOOH. Where indicated, $1 \mu \mathrm{M}$ oligomycin (Oligo) and/or $1 \mu \mathrm{M}$ cyclosporin A (CsA) were added to the incubation medium. $\Delta \Psi_{\mathrm{m}}$ was determined as the ratio of $\mathrm{DioC}_{6}(3)$ fluorescence $(\mathrm{F})$ in the absence of $50 \mu \mathrm{M} \mathrm{CCCP}$ to that in its presence $\left(\mathrm{F} / \mathrm{F}_{\mathrm{CCCP}}\right) .{ }^{*} \mathrm{p}<0.05$ vs. respective $\mathrm{CTR}$ group; ${ }^{\#} \mathrm{p}<0.05$ vs. lymphocytes treated only with oligomycin.

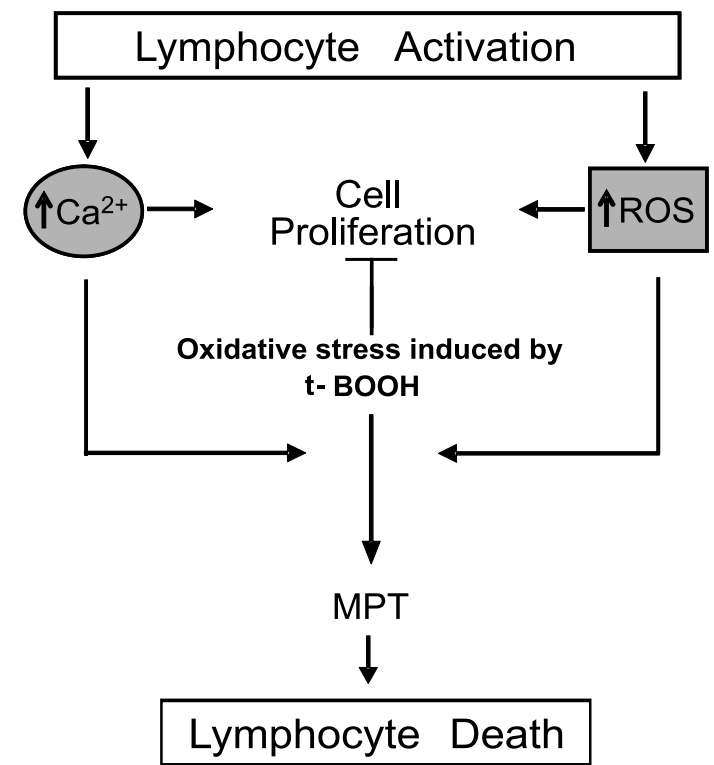

Fig. 8 - Summary of the effects of t-BOOH-induced oxidative stress on pathways involved in proliferation and death of activated lymphocytes. The process of lymphocyte activation involves both ROS overproduction and increases in $\left[\mathrm{Ca}^{2+}\right]_{\text {cyt }}$. Treatment with agents that induces cellular oxidative stress (e.g. t-BOOH) leads to a conversion of the physiological signals from proliferation to death of activated lymphocytes. $\mathrm{t}$-BOOH induces oxidative stress by exhausting cellular antioxidants and promoting free radicals generation. t-BOOH results in necrotic death mediated by mitochondrial permeability transition (MPT) induction. 
icity seems to be mediated by increased $\left[\mathrm{Ca}^{2+}\right]_{\mathrm{cyt}}$ and MPT (Fig. 8). These findings may contribute to the understanding of increased fragility of the immunological system to chemotherapy-generated oxidative stress.

\section{ACKNOWLEDGMENTS}

The authors thank Edilene S. Siqueira and Elisangela J. Gomes for their technical assistance and Linda El-Dosh for the linguistic revision of the manuscript. The work was supported by Fundação de Amparo à Pesquisa do Estado de São Paulo (FAPESP), Conselho Nacional de Desenvolvimento Científico e Tecnológico $(\mathrm{CNPq})$ and Coordenação de Aperfeiçoamento de Pessoal de Nível Superior (CAPES).

\section{RESUMO}

O presente estudo demonstra que linfócitos ativados de baço de ratos portadores do tumor de Walker 256 são mais susceptíveis à morte celular necrótica induzida por tert-butil hidroperóxido (t-BOOH) in vitro quando comparados aos controles. $\mathrm{O}$ quelante de ferro e antioxidante deferoxamina, o quelante intracelular de $\mathrm{Ca}^{2+}$ BAPTA, o antagonista de canal de $\mathrm{Ca}^{2+}$ nifedipina ou o inibidor da transição de permeabilidade mitocondrial ciclosporina-A, mas não o inibidor de calcineurina FK-506, inibiram de maneira similar a morte celular induzida por t-BOOH em linfócitos ativados e controles. Os linfócitos ativados apresentaram redução do potencial de membrana mitocondrial induzida por t-BOOH num mecanismo sensível a ciclosporina-A. Nossos resultados indicam que o aumento da concentração de $\mathrm{Ca}^{2+}$ citosólico em linfócitos ativados aumenta a susceptibilidade dos mesmos à morte celular induzida por estresse oxidativo, num mecanismo envolvendo a participação do poro de transição de permeabilidade mitocondrial.

Palavras-chave: morte celular, radicais livres, resposta imune, linfopenia, transição de permeabilidade mitocondrial, esplenócitos.

\section{REFERENCES}

ABE K AND SAIto H. 1998. Characterization of t-butyl hydroperoxide toxicity in cultured rat cortical neurones and astrocytes. Pharmacol Toxicol 83: 40-46.

Arnold R, Brenner D, BeCKer M, Frey CR AND KRAMMER PH. 2006. How T lymphocytes switch between life and death. Eur J Immunol 36: 1654-1658.
Bartesaghi S, Trujillo M, Denicola A, Folkes L, WARDMAN P AND RADI R. 2004. Reactions of desferrioxamine with peroxynitrite-derived carbonate and nitrogen dioxide radicals. Free Radic Biol Med 36: 471-483.

Bartoli GM, Piccioni E, Agostara G, Calviello G AND PAlozzA P. 1994. Different mechanisms of tertbutyl hydroperoxide-induced lethal injury in normal and tumor thymocytes. Arch Biochem Biophys 312: 81-87.

Bernardes CF, Pereira da Silva L and Vercesi AE. 1986. t-Butylhydroperoxide-induced $\mathrm{Ca}^{2+}$ efflux from liver mitochondria in the presence of physiological concentrations of $\mathrm{Mg}^{2+}$ and ATP. Biochim Biophys Acta 850: $41-48$.

BOYUM A. 1976. Isolation of lymphocytes, granulocytes and macrophages. Scand J Immunol Suppl 5: 9-15.

Brumatti G, Weinlich R, Chehab CF, Yon M and Amarante-Mendes GP. 2003. Comparison of the antiapoptotic effects of Bcr-Abl, Bcl-2 and Bcl-x(L) following diverse apoptogenic stimuli. FEBS Lett 541: 57-63.

ButTKE TM AND SANDSTROM PA. 1995. Redox regulation of programmed cell death in lymphocytes. Free Radic Res 22: $389-397$.

CAmpos CB, Degasperi GR, Pacifico DS, Alberici lC, Carreira RS, Guimarães F, Castilho RF AND VERCESI AE. 2004. Ibuprofen-induced Walker 256 tumor cell death: cytochrome c release from functional mitochondria and enhancement by calcineurin inhibition. Biochem Pharmacol 68: 2197-2206.

Castilho RF, Kowaltowski AJ, Meinicke AR, Bechara EJ And Vercesi AE. 1995. Permeabilization of the inner mitochondrial membrane by $\mathrm{Ca}^{2+}$ ions is stimulated by t-butyl hydroperoxide and mediated by reactive oxygen species generated by mitochondria. Free Radic Biol Med 18: 479-486.

ConkLIN KA. 2004. Chemotherapy-associated oxidative stress: impact on chemotherapeutic effectiveness. Integr Cancer Ther 3: 294-300.

Crompton M, Ellinger H And Costi A. 1988. Inhibition by cyclosporin $\mathrm{A}$ of $\mathrm{Ca}^{2+}$-dependent pore in heart mitochondria activated by inorganic phosphate and oxidative stress. Biochem J 255: 357-360.

Crompton M. 1999. The mitochondrial permeability transition pore and its role in cell death. Biochem J 341: 233-249.

DAly MJ, Young RJ, Britnell SL And NAYler WG. 1991. The role of calcium in the toxic effects of tert-butyl hydroperoxide on adult rat cardiac myocytes. J Mol Cell Cardiol 23: 1303-1312. 
Degasperi GR, Velho JA, Zecchin KG, Souza CT, Velloso LA, Borecký J, CASTILHo RF AND VERCESI AE. 2006a. Role of mitochondria in the immune response to cancer: a central role for $\mathrm{Ca}^{2+}$. J Bioenerg Biomembr 38: 1-10.

Degasperi GR, ZeCCHIN KG, Borecky J, CruZ-HoFling MA, Castilho RF, Velloso LA, GuimaRÃES F AND VERCESI AE. 2006b. Verapamil-sensitive $\mathrm{Ca}^{2+}$ channel regulation of Th1-type proliferation of splenic lymphocytes induced by Walker 256 tumor development in rats. Eur J Pharmacol 549: 179-184.

Doroshow JH. 1983. Anthracycline antibiotic-stimulated superoxide, hydrogen peroxide, and hydroxyl radical production by NADH dehydrogenase. Cancer Res 43 : 4543-4551.

FESKE S. 2007. Calcium signalling in lymphocyte activation and disease. Nat Rev Immunol 7: 690-702.

Friberg H, Ferrand-Drake M, Bengtsson F, HalesTRAP AP AND WIELOCH T. 1998. Cyclosporin A, but not FK 506, protects mitochondria and neurons against hypoglycemic damage and implicates the mitochondrial permeability transition in cell death. J Neurosci 18: 51515159.

Galat A. 2003. Peptidylprolyl cis/trans isomerases (immunophilins): biological diversity - targets - functions. Curr Top Med Chem 3: 1315-1347.

Giardini C, La Nasa G, Contu L, Galimberti M, Polchi P, ANGELUCCI E, BARONCIANI D, BARbanti I, Muretto P and Lucarelli G. 1993. Desferrioxamine therapy induces clearance of iron deposits after bone marrow transplantation for thalassemia: case report. Bone Marrow Transplant Suppl 1: 108-110.

Goldstein S AND CZAPSKI G. 1990. Transition metal ions and oxygen radicals. Int Rev Exp Pathol 31: 133-164.

Green DR And Kroemer G. 2004. The pathophysiology of mitochondrial cell death. Science 305: 626-629.

GREen DR AND REed JC. 1998. Mitochondria and apoptosis. Science 281: 1309-1312.

GRIFFITHS EJ AND HALESTRAP AP. 1991. Further evidence that cyclosporin A protects mitochondria from calcium overload by inhibiting a matrix peptidyl-prolyl cis-trans isomerase. Implications for the immunosuppressive and toxic effects of cyclosporin. Biochem J 274: 611-614.

Grossman Z, Min B, Meier-Schellersheim M and PAUL WE. 2004. Concomitant regulation of T-cell activation and homeostasis. Nat Rev Immunol 4: 387-395.

HALliWell B. 1989. Protection against tissue damage in vivo by desferrioxamine: what is its mechanism of action? Free Radic Biol Med 7: 645-651.

Hartley A, Davies M and Rice-Evans C. 1990. Desferrioxamine as a lipid chain-breaking antioxidant in sickle erythrocyte membranes. FEBS Lett 264: 145-148

Hermiston ML, Xu Z, Majeti R and Weiss A. 2002. Reciprocal regulation of lymphocyte activation by tyrosine kinases and phosphatases. J Clin Invest 109: 9-14.

Hoe S, Rowley DA and Halliwell B. 1982. Reactions of ferrioxamine and desferrioxamine with the hydroxyl radical. Chem Biol Interact 41: 75-81.

JoCELYN PC AND DiCKSON J. 1980. Glutathione and the mitochondrial reduction of hydroperoxides. Biochim Biophys Acta 590: 1-12.

Kennedy CH, Church DF, Winston GW and Pryor WA. 1992. tert-Butyl hydroperoxide-induced radical production in rat liver mitochondria. Free Radic Biol Med 12: $381-387$.

Kowaltowski AJ, Castilho RF AND Vercesi AE. 2001. Mitochondrial permeability transition and oxidative stress. FEBS Lett 495: 12-15.

Krammer PH, ARNOLD R AND LAVRIK IN. 2007. Life and death in peripheral $T$ cells. Nat Rev Immunol 7 : $532-542$.

LEMASTERS JJ ET AL. 1998. The mitochondrial permeability transition in cell death: a common mechanism in necrosis, apoptosis and autophagy. Biochim Biophys Acta 1366: 177-196.

Mackall CL, Fleisher TA, Brown MR, Magrath IT, Shad AT, Horowitz ME, Wexler LH, Adde MA, MCCluRE LL AND GReSS RE. 1994. Lymphocyte depletion during treatment with intensive chemotherapy for cancer. Blood 84: 2221-2228.

Martin SJ, Reutelingsperger CPM, MCGahon AJ, RADER J, VAN SCHIE RCAA, LAFACE DM AND GREEN DR. 1995. Early redistribution of plasma membrane phosphatidylserine is a general feature of apoptosis regardless of the initiating stimulus: inhibition by overexpression of Bcl-2 and Abl. J Exp Med 182: 1-12.

Mather MW And RotTenberg H. 2002. The inhibition of calcium signaling in T lymphocytes from old mice results from enhanced activation of the mitochondrial permeability transition pore. Mech Ageing Dev 123: 707-724.

Nieminen AL, Byrne AM, Herman B And Lemasters JJ. 1997. Mitochondrial permeability transition in hepatocytes induced by $\mathrm{t}-\mathrm{BuOOH}$ : $\mathrm{NAD}(\mathrm{P}) \mathrm{H}$ and reactive oxygen species. Am J Physiol 272: C1286-C1294. 
Quintana A, Griesemer D, Schwarz EC ANd Hoth M. 2005. Calcium-dependent activation of T-lymphocytes. Pflugers Arch 450: 1-12.

Rottenberg H AND Wu S. 1998. Quantitative assay by flow cytometry of the mitochondrial membrane potential in intact cells. Biochim Biophys Acta 1404: 393-404.

ROY CR. 2003. Immunology: professional secrets. Nature 425: 351-352.

Stahnke K, Fulda S, Friesen C, Strauss G and DEBATIN KM. 2001. Activation of apoptosis pathways in peripheral blood lymphocytes by in vivo chemotherapy. Blood 98: 3066-3073.
WALlace KB. 2003. Doxorubicin-induced cardiac mitochondrionopathy. Pharmacol Toxicol 93: 105-115.

WILLIAMS MS AND KWON J. 2004. T cell receptor stimulation, reactive oxygen species, and cell signaling. Free Radic Biol Med 37: 1144-1151.

ZORATTI M AND SZABO I. 1995. The mitochondrial permeability transition. Biochim Biophys Acta 1241: 139-176. 